\title{
Erratum to: Reservoir Impact Assessment on Land Use/Land Cover and Infrastructure-A Case Study on Polavaram Project
}

\section{Ramprasad Naik Desavathu • \\ Suryaprakasarao Bosukonda • \\ Mrutyunjayareddy Kamireddy}

Published online: 15 October 2011

(C) Indian Society of Remote Sensing 2011

Erratum to: J Indian Soc Remote Sens (2011) 39:271-278

DOI 10.1007/s12524-011-0086-2

The original version of this article unfortunately contained an inadvertent mistake.

Author's name has been unintentionally misspelled.

Correct author's name is Ramprasad Naik Desavathu.

The online version of the original article can be found at http:// dx.doi.org.10.1007/s12524-011-0086-2.

\footnotetext{
R. N. Desavathu

Department of Geo-engineering, College of engineering,

Andhra University,

Visakhapatnam 530 003, India

S. Bosukonda $(\square)$

Gandi Institute of Technology and Management,

Pinagadi,

Visakaptanam 531 173, India

e-mail: bosukonda@rediffmail.com

M. Kamireddy

Andhra Pradesh State Remote sensing Center,

2nd floor, DES campus, Kairatabad,

Hyderabad 500004 Andhra Pradesh, India
} 